\title{
Human agency, historical inevitability and moral culpability: Rewriting black-white history in the wake of Native Title
}

\author{
Shayne Breen
}

\begin{abstract}
Whatever may be the evils of society in a state of civilization they are assuredly less in character and degree than those of savage life; and I can never regret that the fair and beautiful country of Tasmania has been entirely reclaimed from the dominion of the debased and treacherous Aborigines; though I cannot but comment that it has been done in part in sad violation of those laws established by Him who hath made of one blood all men to dwell upon the face of the earth.
\end{abstract}

In the 1993 Native Title debate, Geoffrey Blainey sketched a version of the history of black-white contact in Australia in which he sought to cast doubt on the need for native title legislation. In a series of newspapers articles and the occasional reported speech, Blainey articulated a position on native title which argues that in the course of dispossession most Aborigines died from disease and that Aboriginal society would inevitably decline in the face of the natural planetary spread of superior western civilisation. Blainey delivered these views in support of his position that the then federal Labour government was being too generous to the country's Aborigines in what he sees as a guilt-ridden and politically-correct attempt to make reparation for perceived past wrongs. ${ }^{2}$ In his criticism of the High Court Mabo decision, Blainey argued that the judges were told the wrong story of the past; Blainey's story, presumably, is the right one. Here we have the self-proclaimed historiographical objectivist accusing supporters of native title of propagating a fashionable political-correctness, ignoring the political motivation which informs his own views-aptly described by Humphrey McQueen as the defence of the Australian mining industry.

Many Australians have little awareness that historians' interpretations of evidence are, in larger or smaller degree, influenced by personal values and interests. For many Australians, history is fact, not interpretation. So when an historian with the profile of Blainey asserts publicly that most Aborigines died from disease, and that it was inevitable they would be overrun in any case, many Australians will believe that he is stating historical fact. But as Henry Reynolds and Gillian Cowlishaw have argued,

\footnotetext{
${ }^{2}$ Weston 1843 , pp 93-4.

${ }^{2}$ Blainey, July and November, 1993.

${ }^{3}$ McQueen 1994, p. 55.
} 
Blainey's position is open to debate, not only in terms of its substantive claims but also in terms of what Blainey neglects to mention. In particular, Blainey's emphasis on disease as the major cause of Aboriginal deaths, while it may be statistically correct, deflects attention from the extent of murder as a major cause of deaths. This debate between Reynolds and Cowlishaw on the one hand and Blainey on the other is but one further episode in the now long-running debate between colonial and post-colonial versions of race relations in Australia's past. ${ }^{4}$

The historical debate at the national level has been replicated by historians, both amateur and professional, at the local level. The story of Aboriginal dispossession in the Deloraine district of northern Tasmania illustrates this process of selective remembering. In the 1890s Daniel Griffen, the journalist son of an Irish immigrant, recorded in passing the dispossession and what he saw as the sad fate of the Pallittorre. In 1964, J. R. Skemp, formerly a science teacher, recognised the reality of dispossession and gave it a place in his short history of the district. More recently, Simon Cubit, a leading advocate of the claims of cattle owners and horse riders wishing to practise their 'traditional' pursuits on the plateau which overlooks the Deloraine district, described the process of early British occupation of the Meander district without acknowledging either the prior occupation by the Pallittorre or their resistance to the British invasion. Cubit portrays the stock-keepers and their masters as 'bold' and 'ambitious', as heroic pioneers involved in a sequential process of occupying the wilderness and miraculously transforming it into productive grazing land. Cubit's approach, which typifies the historiography of racial contact in Australia from the 1880s until the early 1970s, amounts to a denial of the existence of the Pallittorre, and hence a distortion of historical truth. This kind of selective amnesia needs to be challenged by a more rigorous analysis of the process of colonisation. ${ }^{5}$

My purpose in this paper is to challenge the historical props on which Blainey and others argue against the need for some form of reparation. I seek to show that blackwhite relations in Van Diemen's Land, and especially in Pallittorre country, were more complex and problematic than Blainey's over-generalised explanations recognise. I argue that Aborigines sought to resolve disputes in ways in which violent contact was limited, and that they used the threat of force as a major weapon. In contrast, the British regularly practised promiscuous massacre, a practice fuelled by the belief that in relations with Aborigines force was necessary. These arguments involve not only the question of how Aborigines died but also the thinking, both black and white, which informed the various uses of force. I argue also that notions of the British invasion and subsequent Aboriginal deaths as inevitable outcomes of broad historical forces are little more than figments of conservative historical imaginations, most notably those of John West and Geoffrey Blainey. More to the point, Blainey's arguments, and West's, are contrived to deny the proposition that historical actors choose and execute courses of action for which they must bear responsibility.

\footnotetext{
${ }^{4}$ Reynolds 1993, p. 19; Cowlishaw 1993, pp. 15 and 24.

${ }^{5}$ Griffen 1893-4, p39. Griffen's pieces were first published in 1893-94 in the Launceston Daily Telegraph; Skemp 1964, pp. 10-11, Cubit, 1987, p. 11; Hartwig, 1971, pp. 9-24.
} 


\section{Resisting the invader}

In the following analysis of Pallittorre relations with the British colonists I have used Rhys Isaac's ethnographic approach of discerning historical actors' intentions and motivations from their reported actions. Ethnographic analysis allows the historian to imaginatively enter into the circumstances and perhaps mentality of historical actors who have left no written records. The method requires that reported behaviours, which are regarded as action-statements, be understood in the context of the cultural assumptions and values the historical actors in question were likely to have applied in the reported situation. Further, situations or incidents understood in this way should be recurrent incidents which can be seen as typical or even symbolic of relations between competing cultural groups, in this case indigenous people in Tasmania and their British colonisers. $^{6}$

William Knight and John Hurling lived and worked as stock-keepers on the land occupied by Thomas Cookson Simpson (Figure 2). ${ }^{7}$ John Hurling was an assigned convict and Knight was his overseer. Abandoned in this place by their master, theirs was a lonely and sometimes fearful existence. Roads and hence communications were poor, and housing very basic, little more than mud huts with bark rooves. At the time only a small number of British men lived in the district: three free colonists, all of whom were working as overseers for absentee cattle graziers; a few assigned convicts; and a small number of soldiers and police whose job it was to help protect the colonists and their cattle and sheep from bushrangers and Aborigines. No white women lived in this colonial outpost.

On the night of 22 June 1827, Knight and Hurling were sitting in their stock-hut. The hut's fireplace smoked a great deal that night, a fact which irritated Knight. Denied the small comfort of a blazing fire on a cold winter's night, Knight remarked to Hurling, perhaps sarcastically, that he wished 'the natives would come and burn down the bloody hut tomorrow morning'. About noon the following day, Saturday 23 June 1827 , Knight and Hurling were working some thirty yards from their hut. They had felled a tree for firewood and were engaged in lopping its branches. Despite being only thirty yards from their hut, Knight and Hurling had taken their muskets with them, although when rain began to fall they returned the muskets to the hut. Disregarding the rain, the two men returned to their work. A creek, its banks protected by a cluster of tea tree brush, flowed past the front of their hut. Unknown to them, a group of Pallittorre were hiding in the brush. In due time, according to Hurling, 'a number of black native people rushed into the hut and took possession of it'. Armed with hatchets and protecting their heads with their arms, Kright and Hurling moved towards the hut but were met by a hail of spears. One of the spears, thrown by a tall black man, struck Knight in the left shoulder. Knight pulled the spear from his shoulder and as he did so waved his hands

\footnotetext{
"Isaac 1982, pp. 323-29.

${ }^{7}$ Depositions concerning the death of William Knight, 1827, 1/316, Chief Secretary's Office, Hobart. Unless otherwise indicated the information in the following section is drawn from these depositions. Four statements were given to P.A. Mulgrave, police magistrate at Launceston, between $26-30$ June 1827 . The statements were given by a police constable, a soldier, an overseer of convicts and an assigned convict.
} 


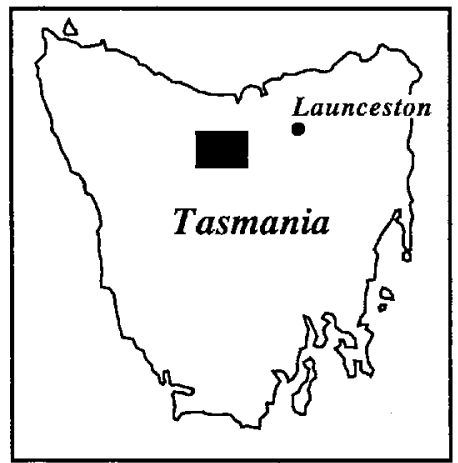

Map 1: Pallittorre country

in Northern Tasmania

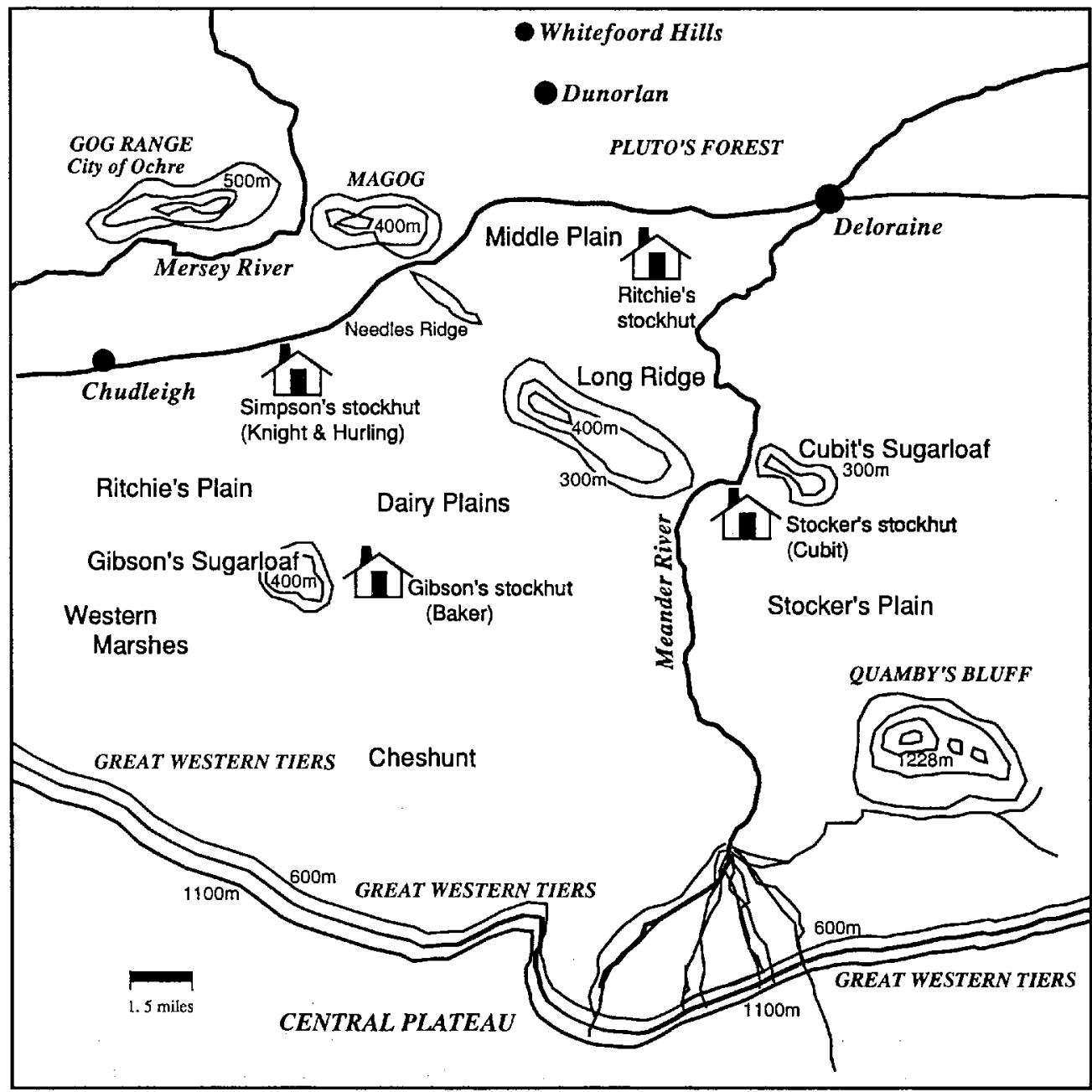

Map 2: The Westward's Killing Fields: Pallittorre country and the scene of William Knight's death. 'Based on the Land Commissioners' maps, 1826-28. 
to Hurling. Hurling, supposing that Knight meant him to run from the attackers, ran onto the adjacent plain, which was ankle deep in water, and towards Gibson's hut, some three miles to the south-east, in search of help. Knight slowly followed Hurling, but about 200 yards from the hut, two or three blacks knocked Knight down. In line with the practice followed by other Tasmanian Aborigines, the Pallittorre killed Knight by beating him around the head with waddies. They also used a garden hoe. The blacks then returned Knight's body to within fifteen yards of his hut. A rope made of native grasses was used to drag the body, which had a black mark around its neck, from the plain to the hut. The rope was later found by whites at the blacks' camp. When Knight's body was found by Hurling and some others, it was on its back, the legs were crossed, one arm was under the head and the other under a side, and a dark coloured cotton handkerchief covered the face. Knight usually kept this handkerchief in his kangaroo skin cap, which was lying on the ground near his head with some blood in it.

$39582 * 1$ While Knight was meeting his fate, about twenty blacks pursued Hurling across the plain to the edge of the forest. Just prior to entering the forest, Hurling turned and faced a black, who was armed with a spear in each hand, standing some ten to fifteen yards away. Hurling threw his hatchet through the air. The weapon hit it's mark, knocking the black to the ground. Intent on fleeing his attackers, Hurling decided his chances were better without his boots, which were too big for his feet. He unlaced them and threw them off, recalling later he felt he could no longer run with them on. Ankle deep water would not have helped. By now there were about twenty blacks within thirty yards of Hurling, all armed with spears. As he ran, several spears were thrown at him, although none hit. Some three or four hundred yards into the forest, Hurling became tired and was unable to run any further. He noticed among some tall grass a huge fallen tree with a large limb coming off it's side. He clambered under the tree, which was hollow, and laid down with his face to the ground and his hands under his body.

The Pallittorre surrounded the tree where Hurling was 'hiding'. They passed backwards and forwards at both ends of the tree, as they did calling 'Rugga, Rugga', possibly a word for 'go away'. ${ }^{8}$ They kept this up for a short time. Some thirty minutes later, Hurling's dog came to him. Assuming that the blacks were unable to find him and fearing they may have followed his dog, Hurling immediately abandoned his hiding place. So that he might run more freely, he pulled off his trousers, which were sodden, and proceeded to run along a very rough forest road towards Gibson's hut. At some stage either during or after the killing of Knight and the pursuit of Hurling, the Pallittorre 'plundered' Simpson's stock-hut. They took with them four whips, a straw hat, a handkerchief, two forks, four spoons, one wooden bucket, a frying pan, five shirts, two pairs of trousers, a pair of boots, a waistcoat and a blue jacket; they also took a quantity of flour, thirty pounds of sugar, twelve pounds of tea and three pounds of soap. They left a bucket, a frying pan, two iron pots, a grubbing hoe and a mortising tool. Outside the hut they left forty pounds of salt. They burst open several bags containing eighteen bushels of wheat, and scattered the grain about the hut and outside the door. These actions by the Pallittorre severely disrupted Hurling's capacity to remain at the hut and perform the colonising tasks his master had assigned to him.

\footnotetext{
${ }^{\mathrm{K}}$ I was unable to find any reference to this word.
} 
Hurling arrived at Gibson's stock-hut about 3 o'clock. Waiting there to greet this unexpected visitor were Henry Smith, William White, Thomas Baker, field police constable Thomas Williams and two soldiers, corporal James Lingan and corporal John Shiners. Smith and White were both convicts, assigned to David Gibson, their absentee landlord, himself a former convict. Baker was their overseer. Hurling, wearing only a shirt and with his trousers in one hand, ran straight into the hut and sat down on a stool. He was out of breath, on the point of exhaustion, and, according to the occupants of Gibson's hut, pale and frightened. It was some time before he could speak. When he could, Hurling told Smith 'Oh! My mate is killed, the natives have been and killed my mate along side of me.' Almost immediately a party comprising police constable Williams, corporal Shiners, Baker, Hurling and Smith left for Simpson's hut. They found Knight's body where the Pallittorre had left it, some fifteen yards from his hut. The Pallittorre were nowhere to be seen. Williams observed both large and small barefoot foot prints, indicating both adults and children were in the Pallittorre party. Smith estimated 30 people; their footmarks 'were all over the Garden like the footmarks of so many Cattle'. The whites returned to Gibson's hut. The following day, Sunday 24 June, Shiners, Williams and Lingan, accompanied by Baker and White, set off in pursuit of the Pallittorre. About two in the afternoon Shiners noticed the smoke of a fire which he judged to be near Laycock's Falls, some five miles west of Gibson's hut. Arriving at the falls about an hour before sundown, the pursuers hid in a hollow tree some 400 yards from the blacks' camp. Two blacks, armed with spears, stood guard, suggesting an expectation of revenge.

The British response to Knight's death suggests they adapted their military practice to a form of guerrilla warfare. Between seven and eight o'clock the whites crept to within 40 yards of the blacks' camp. Six fires were burning. Three were close together, and the other three 14 to 15 yards away. About 30 blacks and a number of dogs were at the first clustering of three fires. Without calling out and under the cover of darkness, the whites, with pistols blazing, rushed the Pallittorre camp. A 'great number of black native people' ran from their camp and 'immediately disappeared amongst some scrub and ferns'. No blacks cried out. Like other Tasmanian Aborigines, the Pallittorre were quick to incorporate British hunting dogs into their hunting practices. As the Pallittorre fled in to the night at Laycock's Falls, their dogs attacked their assailants. Throughout the course of the night the whites shot upwards of 25 of these dogs. The evidence makes no mention of any intention to take prisoners. Williams, Shiners and their accomplices were intent on reprisal, not on implementing the rule of law. ${ }^{9}$ Both Williams and Shiners were at pains to point out they had not called out prior to their attack. This was significant because in British military tradition, surprise ambushes were considered to be dishonourable. This, however, was a silent war, unannounced in the immediacy of its execution, requiring great patience and cunning in the quest for advantage.

Next morning, no black bodies could be found, although Williams saw tracks of blood near the fires. He was quite sure at least one black had been shot. He traced the track of blood over two logs; between the logs he saw 'the prints of naked human feet, close to the track of blood'. In contrast, Shiners did 'not think that any of them had been

\footnotetext{
${ }^{9}$ See Neal 1991, pp. 17-18, 58, 78-80, for a discussion of the non-application of the rule of law to Aborigines in New South Wales prior to 1860.
} 
wounded' or killed. Not surprisingly, the blacks did not return to their camp. The whites remained at the camp until about ten o'clock the following morning, but to no avail. They returned to Gibson's hut; soon after, they set out for Launceston to tell their stories to the police magistrate. Knight's death prompted a horrible revenge. Soon afterwards, the Hobart Colonial Times reported that 'The people over the second Western Tier have killed an immense quantity of the blacks this last week, in consequence of their having murdered Mr Simpson's stock-keeper. They were surrounded whilst sitting round their fires, when the soldiers and others fired at them when about thirty yards distant. They report that there must be about sixty of them killed and wounded'. ${ }^{10}$

Why was William Knight killed? There is one very specific reason for the killing. An informant called Punch told Robinson that Knight deserved to be killed because he 'used to kill the natives for sport', ${ }^{11}$ Using the depositions taken by Mulgrave, we can discern at least two other specific reasons for the Pallittorre attack on Knight's hut: to 'plunder' the hut, taking some of the contents and destroying others; and to scare Hurling away. So the Pallittorre had very specific reasons for the ritual killing of Knight. But the' location of Knight's death in appropriate wider contexts allows a deeper understanding of the Pallittorre motivation for killing him. In particular, the broader context of the Black War in Van Diemen's Land, and prior relations with Europeans living in Pallittorre country are appropriate contexts; and Knight's killing also needs to be understood within the contexts of Aboriginal expectations concerning reciprocal exchange and conflict resolution.

In early 1803, the Aboriginal land then known by the European world as Van Diemen's Land was invaded by Britain. Following a decade of living in survival mode in both the north and the south of the island, the colonisers gradually occupied the Aboriginal hunting grounds between Launceston and Hobart, as well as on the east coast of the island. Through the 1820 s, colonisation intensified into river valleys adjacent to the central corridor between Launceston and Hobart, and into what was referred to by the colonists as the Westward, a series of Aboriginal hunting grounds stretching westward some thirty miles from Launceston to what became known as Deloraine. At the end of this northern corridor was Pallittorre country. (see Map 3) ${ }^{12}$ The intensification of colonisation in the 1820 s occasioned a vigorous and extremely effective resistance by the island's Aboriginal owners. The Black War was well underway by the mid-1820s but was at its fiercest in the late $1820 \mathrm{~s}^{13}$ The extent of land in Pallittorre country suitable for grazing, some 31,000 acres, ${ }^{14}$ ensured it was a target for the invaders. From about 1823 onwards, British squatters began moving cattle and stockkeepers onto Pallittorre land. Chief among these was William Field, formerly a convict,

\footnotetext{
"Hobart Colonial Times, 6 July 1827.

"Plomley 1966, p. 219; In 1830, information about black-white relations in the Deloraine district was given to the diarist G.A. Robinson by a stock-keeper called Punch. Punch worked on a stock-run at Avenue Plains, near Parkham, some 10 kilometres west of Deloraine township. Born in London, he was a former convict who had also been a constable. Robinson described him as very civil, and was impressed by the fact that Punch gave Truganini, who was travelling with Robinson, a new pair of shoes.

${ }^{12}$ Ryan 1981, p. 83.

${ }^{13}$ Ryan 1981, p. 139.

${ }^{14}$ Cubit 1987, p. 10.
} 
who by the mid-1820s had acquired ownership of large numbers of cattle and sheep. Field sold most of his produce to the government store in Launceston, ${ }^{15}$ a commercial relationship suggestive of government acceptance of this 'unofficial' occupation. No record of hostility in the period from 1823 until late 1826 exists. The effective dispossession of the Pallittorre occurred in the late $1820 \mathrm{~s}$, during the second phase of pastoral expansion in Van Diemen's Land.

A concerted resistance occurred across the Central North during late Spring and early Summer of 1827. At least 19 separate incidents occurred in this period, including nine incidents between 10-24 November. At least eight whites were killed, in addition to spearings, other woundings and general harrassments. Huts were plundered and burnt, and at least 100 sheep were killed at the Lake River. ${ }^{16}$ Between 2-7 December,

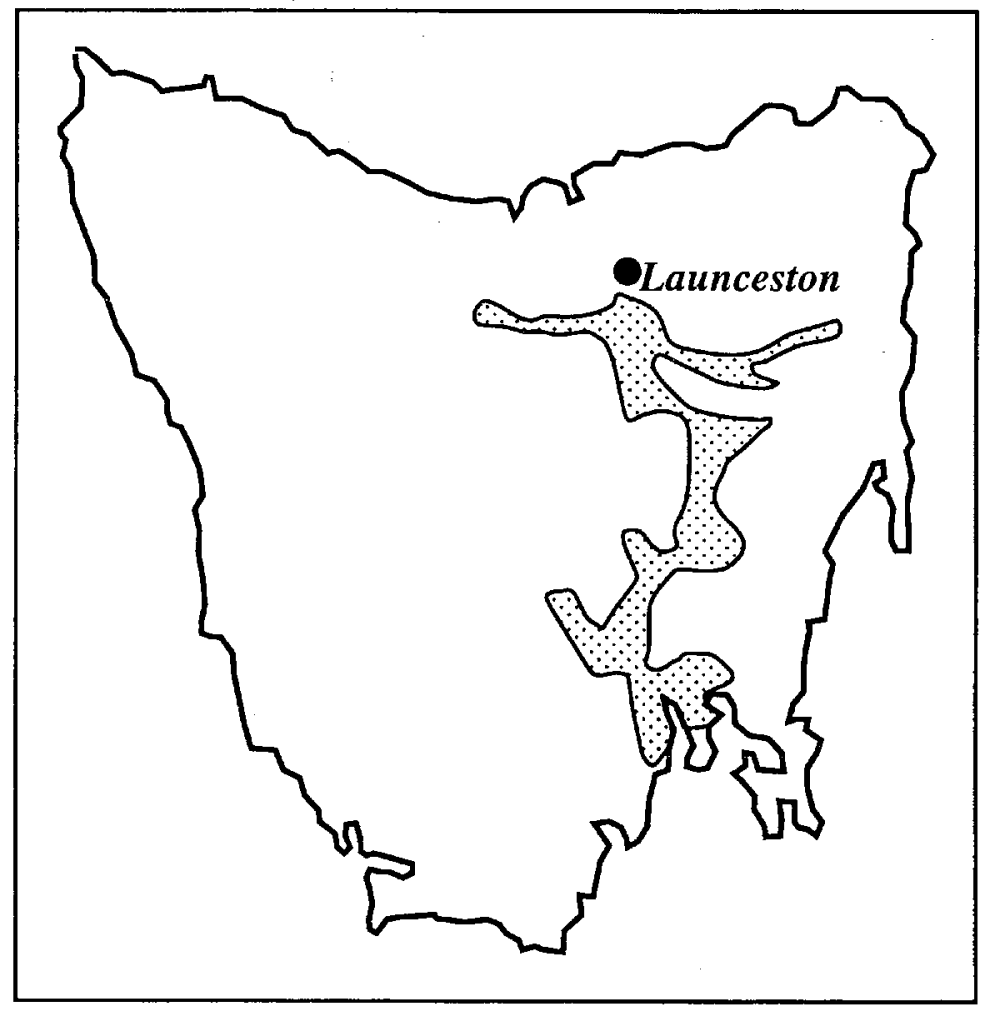

Map 3: Occupation of Aboriginal Land to the late 1820s, Van Diemen's Land.

\footnotetext{
${ }^{15}$ Correspondence file, William Field, 71/227, Archives Office of Tasmania.

${ }^{16}$ Plomley 1992, pp 44-51.
} 
several travellers were harrassed on the Launceston to Hobart Road. But when we examine relations between the Pallittorre and the stock-keepers living in their country prior to Knight's death, we gain a more substantial insight into the local context for Knight's killing and the nature of the violence which characterised the conflict. A series of incidents, involving Pallittorre attempts at negotiation, raids on stock-huts, the theft of women and children, and killings of blacks preceded Knight's death.

About six months prior to the attack, in the previous summer, 'about twenty of the native people came to the hut and remained in the neighbourhood of the hut the whole of the day'. Almost certainly the Pallittorre on this occasion sought to induce Knight to fulfil his reciprocal obligation to them. ${ }^{17}$ Knight, who had been an 'associate' of the blacks in Sydney, spoke to them in their own language and they went away. No spears were thrown, no shots were fired. Relative harmony prevailed, although the appearance of harmony probably masked developing tensions. About three months prior to his death Knight told Hurling that he had 'fallen in with some natives and fired at them, and that three spears which he had brought home with him, had been thrown at him: Hurling's account of the information related to him by Knight suggests that Knight was the aggressor in this incident. No other information concerning this incident is available. It is very likely Knight's death was related to these earlier incidents. More generally, the theft of women and children may have persuaded the Pallittorre to take revenge on Knight. Punch told Robinson that he asked a black who could speak English why they killed Europeans. He was told 'if black man came and took away his lubras and killed his piccaninnies, would he not kill black man for it?'

The Pallittorre punishment of William Knight was also almost certainly in response to an incident just eleven days prior to their attack on Simpson's hut. On 12 June, some two hundred blacks surrounded Gibson's hut. They isolated Thomas Baker from the hut, hence he was unable to get his gun. One of the blacks threw a spear at him, which missed. The black then approached Baker, apparently without a weapon. According to Punch, Baker produced 'a long knife he had in a case by his side and ripped up his [the black's] belly and ran away'. The black died from this wound. Despite this incident, the Pallittorre remained in the district overnight, a decision, as events transpired, which proved fatal. Baker's retribution was both swift and brutal. He went immediately to Stocker's stock-hut (Map 2), where James Cubit and his 'half-caste' Aboriginal mistress lived. That night, guided by the Pallittorres' fires, Baker, Cubit and Cubit's mistress went to the blacks' camp and killed nine of them. Cubit was reputed to have killed more blacks than any other man in the colony. ${ }^{18}$

After Baker 'escaped' on the day of 12 June, the Pallittorre raided his hut. Baker did not become aware of this 'plunder' until the following day; his actions the night before were therefore in response to several other factors: the approach by the black he had killed; being surrounded by two hundred blacks (an estimate made in the fear of the moment?); an accumulation of hatred and fear of the blacks; and, as I will discuss below, a belief that violence was a necessary part of black-white contact. The Pallittorre stripped Baker's hut of all its bedding material and clothes. They took seven bushels of

\footnotetext{
${ }^{17}$ See Reynolds 1982, pp. 68-70 and 72-3 for a discussion of the role of Aboriginal reciprocity in Australian race relations.

${ }^{18}$ Plomley 1966, p. 219; Griffen 1893-4, p. 39.
} 
flour, which they used to make damper, all the knives, an axe, two pairs of sheep shears, a pair of scissors, a tomahawk, some gunpowder and all the tin pots. They also took away 30 or 40 kangaroo skins. Clearly, the Pallittorre wanted Baker to leave. They had not come to kill him, but to collect payments owing, to frighten him into leaving and to reduce his capacity to continue colonising their land.

Two markedly different strategies were pursued by the protagonists. The Pallittorre sought to threaten transgressors of expected reciprocal arrangements, either to procure payments due or to induce the colonists to leave, rather than engage in direct conflict; the colonists ignored reciprocal expectations and practised the massacre in response to Aboriginal threats. Baker's version of the story has himself escaping from the blacks. I contend that the Pallittorre allowed Baker to escape. Their business was not to kill him, nor did they respond impulsively to Baker's action. Whatever their feeling about Baker, the Pallittorre felt no immediate need to leave the district, nor to conceal themselves, suggesting they felt no further threat from Baker, at least not in the immediate future. This interpretation is supported by evidence prominent colonist Roderick O'Connor gave to the 1830 Aborigines' Committee. O'Connor told the committee 'the Natives are more anxious to plunder than to murder'. ${ }^{19}$

The various incidents which culminated in the killing of William Knight and the subsequent massacre of up to sixty Aborigines consolidated a pattern of relations between the Pallittorre and the colonists which persisted until the mid-1830s. Following Knight's death, the Pallittorre continued to raid and sometimes burn stock-huts, spear cattle and sheep, and drive away the colonisers. Whitefoord Hills, to the west of Deloraine township, was one popular site of resistance during 1830. At least five separate incidents occurred there, ${ }^{20}$ including one near the Avenue in which 300 sheep were clubbed to death. The Avenue plain had been 'for countless generations the favorite hunting ground of large tribes of natives, owing to the plentifulness of game, kangaroo and wallaby abounding from the Blackamoor to the Rubicon'. ${ }^{21}$ These tactics were met with what only can be described as a series of mass murders. In July 1830, for example, the Pallittorre attacked some stock-keepers and successfully drove them away. Soon afterwards, the Pallittorre leader Quamby, along with several others, was killed. ${ }^{22}$ At Middle Plains (Map 2), also in July 1830, 'Lyons and some others fell in with a tribe of natives and drove them into a small lagoon and shot several, and from there they drove them to the foot of Ritchie's Sugarloaf and shot all the others except an old man and a woman who begged for mercy and were suffered to go away'. ${ }^{23}$ Henry Hellyer, the Van Diemen's Land Company chief surveyor, told Robinson that in 1830 a stock-keeper called Paddy Heagon living at the Retreat, some two miles east of the future Deloraine township, shot nineteen blacks with a swivel gun charged with nails. ${ }^{24} \mathrm{O}^{\prime}$ Connor told the Aborigines Committee that 'Captain Ritchie's [stock-]men, to the westward of

\footnotetext{
${ }^{19}$ Shaw (ed) 1971, p. 54.

${ }^{20}$ Plomley 1992, pp 44-51.

${ }^{21}$ Griffen 1893-4, p26.

${ }^{22}$ Ryan 1981, p. 139.

${ }^{23}$ Plomley 1966, p. 218.

${ }^{24}$ Ryan 1981, p. 139.
} 
Norfolk Plains, used to hunt them on horseback, and shoot them from their horses..$^{25}$ Punch told Robinson that several natives were shot by either Murphy or Murray and two others at the Long Swamp. Punch felt that these men were excessively cruel and that 'in this case they ought to be punished'. ${ }^{26}$

The Pallittorre continued to respond to these assaults with retribution spearings, which were not intended to kill, and with raids on stock-huts. One such attack was made on a stock-hut at Dairy Plains (Map 2) occupied by Thomas Johnson and Dolly Dalrymple. This incident has been written about several times. Dolly is usually presented as heroically resisting a vicious and cowardly assault by a large number of blacks. ${ }^{27}$ A six hour siege is reported to have occurred, and Dolly's heroism is frequently marvelled at because she was a woman and because she was a 'half-caste', the daughter of an English sailor and an Aboriginal woman whom the sailor had abducted. These racist and sexist interpretations always fail to locate the blacks' attack on Dolly's hut within the wider black-white relations in the district. On this occasion the blacks speared Dolly's daughter in the thigh, and they set fire to the hut. While there can be little doubt that the attackers were in a mean mood and that in all probability Dolly acted with great bravery, the interpretations of this incident always seek to 'heroineise' Dolly and 'cowardise' the blacks.

The Pallittorre also regularly harrassed Cubit. In September 1831 Cubit walked from his hut at Stocker's Plain (Map 2) to collect water from a nearby spring. Local legend has it that 'some score or more of spears' were thrown at him. Cubit 'beat a hasty retreat' to his hut but received eight wounds, none fatal, along the way. The blacks made a 'long and determined attack' on the hut but a stockman there 'shot several of them, and the remainder fled to the mountains'. Other Aborigines who frequented the district apparently wearied of the struggle. Sometime in 1830, in response to Arthur's offer of a free pardon to any convict who could 'conciliate' Aborigines, John Benfield approached three blacks. He offered them bread and, putting aside his gun as requested by the blacks, was led to a place beyond Dunorlan (Map 2). From here Benfield took a larger group to the local military party; Benfield subsequently received his pardon. This report suggests that these blacks sent out three of their number to meet Benfield for the purpose of making arangements to 'come in'. Lack of food and weariness of the struggle, or perhaps an unwillingness to engage in the struggle, were reasons why many Aboriginal groups submitted to the invader. Perhaps the brutality and extent of the killings in Pallittorre country also induced these particular blacks to 'come in'.

\section{Attitudes to the use of force}

In the second half of the 1820s, both Aborigines and colonists in Van Diemen's Land adopted practices designed to induce fear and terror in the hearts and minds of their respective enemies. But, as I suggested above; the methods used by the two groups to induce fear and terror differed considerably. The Aborigines were far more imaginative in their use of force than were the British, using different methods to achieve different

\footnotetext{
${ }^{25}$ Shaw (ed) 1971, p. 54.

${ }^{26}$ Plomley 1966, p. 218.

${ }^{27}$ Skemp 1964, pp. 10-11; Veale n.d., pp 83-90.

${ }^{2 *}$ Griffen $1893-4$, pp. 38-9.
} 
ends; for the British, force usually meant mass killings of Aborigines. Indeed the record shows that for the British the mere fact of being black was sufficient cause to warrant the use of extreme and unlawful force against Aborigines.

Lyndall Ryan, for Van Diemen's Land specifically, and Henry Reynolds, on a wider national scale, have written comprehensive analyses of the reasons for Aboriginal resistance, citing such factors as the invasion of their land, the failure of the colonists to accept reciprocity, British killings and abductions of Aboriginal women and children, and a desire for the British to leave. Reynolds has also offered a wide-ranging account of the tactics, both traditional and new, employed by Aborigines across Australia in that resistance. Tactics such as surveillance, retribution spearings and occasional retribution killings were derived from traditional cultural practices. Innovations included the use of British food, which increased mobility and lessened the risk of capture or reprisal; the theft and in some places the use of firearms; economic warfare, such as killing stock, burning haystacks or ruining seed; and selective attacks which also lessened the risk of reprisal. ${ }^{29}$ The Van Diemen's Land experience, including that of the Pallittorre, largely conforms with this explanation of the reasons for resistance and the explication of the tactics used by Aborigines. But the Pallittorre experience, and that of Van Diemen's Land Aborigines generally, suggests that our understanding of the nature of black-white violence can be enhanced by further exploration of two important issues: Aboriginal attitudes to the use of force, as distinct from the tactics used; and the characterisation of Aboriginal resistance as guerrilla warfare.

The evidence for the Pallittorre suggests they never believed that violent killing, or even lesser expressions of force, were necessary or even desirable in their relations with the colonisers. As Punch told Robinson 'when he first came the natives was very peaceable, but they have been drove to commit outrages on the whites by reason of the dire atrocities first committed upon them.. ${ }^{30}$ The evidence prior to the Knight killing suggests they sought to negotiate a reciprocal arrangement with Knight. In their ten years of relations with the British, during which time many of their people were killed, the Pallittorre killed only two whites. ${ }^{31}$ On many occasions they could have killed colonists, but did not. The ambush and killing of William Knight was a premeditated retribution prompted by several factors, both local and non-local, as argued above. On most occasions, Pallittorre hostility involved theft or property damage, or attempts to induce colonists to leave, not the killing of colonists. Given that less than 2500 colonists were killed by Aborigines Australia-wide, ${ }^{32}$ the Pallittorre approach to the use of force seems to have been widespread across Australia. And although colonists were killed, never did Aboriginal violence in Van Diemen's Land come to resemble the often unprovoked promiscuous violence practised by the British. This was not a question of 'primitive' weaponry (captured guns were not used against the colonists), or of lacking the tactical skill-the record shows Aborigines were skilful, creative and witty in their

\footnotetext{
${ }^{29}$ Ryan 1981, ch. 7; Reynolds 1982, pp. 103-110.

${ }^{30}$ Plomley 1966, p. 219.

${ }^{31}$ Plomley 1992, p. 15.

${ }^{32}$ Reynolds 1982, p. 121.
} 
resistance to the British. ${ }^{33}$ Rather, Van Diemen's Land Aborigines chose not to commit atrocities on the scale practised by the British.

One prevailing tendency in the historiography of Tasmanian Aborigines is to assert that the Aborigines were experiencing some kind of slow strangulation of their intelligence at the time of the British invasion. Rhys Jones was the modern populariser of this social-Darwinist notion, and it has manifested itself in a number of ways both before and after Jones presented his thesis in the film The Last Tasmanian. ${ }^{34}$ Along with the myth that Aborigines became extinct with the death of Truganini in 1876, this strangulation myth has been and still is a major factor in the oppression of Tasmanian Aborigines. ${ }^{35}$ In this regard it is important to stress the tactical innovation demonstrated by Van Diemen's Land Aborigines in their responses to the British invaders. Failure to do so not only encourages the contemporary survival of the strangulation myth, it runs the risk of depicting Aborigines in early colonial Tasmania as captives of the topography and their cultural traditions. The issue of Aboriginal adeptness at guerrilla warfare is a case in point. Certainly the topography, the process of gradual occupation by the British, and the weapons preferred by the Aborigines meant guerrilla warfare was an obvious option, but we should be wary of the proposition that guerrilla warfare was a 'natural' development, that Aborigines took to guerrilla warfare as a fish takes to water. Such an assertion tends to imply that the choice to use tactics which historians have conceptualised as guerrilla warfare were not conscious choices, but rather something which Aborigines did 'naturally'. ${ }^{36}$ Certainly they worked to harness advantages available to them, but we need to recognise and acknowledge that creative and intelligent choices were made.

Characterisations such as Jones' notion of strangulation may be unwittingly supported by interpretations about the nature of the Aboriginal military response to the British invasion. Reynolds suggests that many Aboriginal groups moved from 'feud to warfare' in their relations with the British. ${ }^{37}$ In general terms this model does describe a broad movement that did occur. There are three problems, however, associated with this term. One is that it can be interpreted as meaning that the Van Diemen's Land Aborigines were slow to discard responses based on traditional practices; two, the term fails to explain why the shift occurred; and three, the term fails to recognise that some groups who met colonisers for the first time in the mid 1820s, such as the Pallittorre, moved much more quickly into the warfare mode than other groups. The most vigorous and organised resistance in Van Diemen's Land coincided with the rush of occupation in the second half of the 1820s. Until that time, many Aboriginal groups preferred to negotiate solutions, largely on the basis of reciprocity, rather than engage in conflict. Not until the massive escalation of sheep and colonisers in the mid-1820s did warfare develop. Also, the decline in population levels induced survivors to come together, thus creating the impression of a late organisation. This impression tends to obscure the point

\footnotetext{
${ }^{33}$ see Clark 1987, p. 64.

${ }^{34}$ The Last Tasmanian: a story of genocide, 1976, (feature documentary), Sydney, Artis Film Productions Pty Ltd, producer Tom Haydon.

${ }^{35}$ Discussions with Aboriginal colleagues and students over the past seven years have convinced me of this point.

${ }^{36}$ Reynolds 1982, p. 103.

${ }^{37}$ Reynolds 1982, pp. 77-8.
} 
that although the conflict intensified in the late 1820s, reflecting an apparent transition from 'feud to warfare', the tactics used underwent refinement rather than major change during the 1820s. Aboriginal hostility, although more organised in the late 1820s, remained linked to the retribution process, to attempts to drive the colonists away, collect due payments or acquire food. The Pallittorre experience suggests it took them little time to realise they were involved in an open-ended conflict with their invaders. After they confronted Baker, for example, they remained in the immediate vicinity of his hut, leaving them easy targets for the reprisal that night. At that time, they saw that having enacted retribution, that particular matter was closed. But they learned very quickly that this was not the case. After they killed Knight, some ten days later, they travelled some five miles from the scene of the killing and posted sentries to detect evidence of pursuit. ${ }^{38}$

One tactic which has not been emphasised as much as it might have been is that of the threat of force, a tactic closely related to the production of fear in the enemy. Reynolds cites one example of this tactic and Ryan in several instances refers to the Aboriginal intent to intimidate the colonists, ${ }^{39}$ but in my view it deserves greater emphasis. Incidence of the threat of force, a less tangible tactic than the others discussed by Reynolds, needs to be discerned from the ethnographic record. The record for Van Diemen's Land in the late 1820s shows the existence of considerable British fear. During the military operation known as the black line, in September 1830, for example, the government's decision to begin the line below Launceston provoked both fear and outrage in Launceston and surrounding districts. A colonist at George Town, some thirty miles north of Launceston, reported seeing a tribe of some $600-700$ Aborigines preparing to attack Launceston..$^{40}$ At the time there were less than 300 Aborigines still living on the entire island, although the general belief was that some 2,000 were still 'at large'. This capacity for fear reflects the colonists' sense of vulnerability, a vulnerability born of their own perception of Aborigines as treacherous savages as well as the Aboriginal capacity to induce fear. But was British fear merely an outcome of the conflict, and not an outcome deliberately pursued by the Aborigines? We need to be careful not to deny the possibility that Aborigines deliberately decided to use the threat of force and the attendant generation of fear as a powerful weapon in their war against the British, that Aborigines were creative agents in moulding the shape of the conflict, not merely ad hoc responders acting within parameters set by the topography, the British and their own cultural traditions.

Several incidents suggests that Aborigines in Van Diemen's Land used the threat of force as a major weapon in their struggle against the British. Ryan relates an incident at Eastern Marshes, near Oatlands, in October 1824, in which 150 Aborigines, accompanied by 50 dogs, divided into groups, surrounded a stock hut, threw spears and stones, and finally surrounded the hut with fires. Despite a siege lasting in excess of five hours, the two servants who occupied the hut 'escaped'. This incident represents far more than a desire to acquire provisions; occurring at the beginning of the Black War, it can be read

\footnotetext{
${ }^{38}$ Depositions concerning the death of William Knight, 1827, Chief Secretary's Office, $1 / 316$, Archives Office of Tasmania, Hobart.

${ }^{39}$ Reynolds 1982, p 105; Ryan 1981, ch 7.

${ }^{40}$ Launceston Advertiser, 6 July 1830.

${ }^{41}$ Ryan 1981, p. 88.
} 
as a symbolic incident, a display of a range of weapons in a configuration of confinement but exercised primarily as intimidation, demonstrating to the colonists at large that the threat of force and its attendant fear were to become a fact of daily life. The Pallittorre adopted similar tactics. In addition to the Baker incident, twenty or thirty Pallittorre chased John Hurling from the site of Knight's killing, throwing spears at him, all of which missed. In both cases, the Pallittorre threatened the two colonists with force; in neither case was the colonist actually assaulted. These threats of force, read as statements of intent, suggest the Pallittorre wished to convey to the colonists not merely a desire to have them leave, but to frighten them and other potential invaders, to create in the minds of colonists a permanent state of fear. ${ }^{42}$

Other tactics also were designed to induce fear. In the summer of 1827-28 the sudden appearance, after long periods of absence, and open hostility shown by the Luggermairrernerpairrer and Lairmairremener bands of the Big River tribe, the southern neighbours of the Pallittorre, caused panic among the colonists. The decision of the Lairmairremener to split up and work in two adjacent areas along the Ouse and upper Derwent Rivers gave 'the impression of combined strategy'. At other times, constant movement and sudden attacks in unexpected places made capture difficult, thereby keeping fear levels high. ${ }^{43}$ There are numerous reports of Aborigines telling raided colonists they would be back to get them. In December 1829, for example, the Lairmairremener robbed huts near New Norfolk. They speared a settler and took his two pistols; they did not kill him, but told him 'we will give it to you'. ${ }^{44}$ The taking in raids of guns and knives, although there are no reports of those weapons being used in Van Diemen's Land, would almost certainly have enhanced British fear. These tactics produced fear amongst the colonists; such tactics were shaped by the traditional movements of those bands and the local topography, but were also the results of decisions, consciously taken, to induce terror amongst the colonists. Fear was not simply the outcome of tangible tactics; it was also the outcome of an Aboriginal policy of terror. The threat of force, and the fear such threats engendered, rather than tangible violence itself, was a major, if not the major weapon used.

The savagery of the British reaction to Aboriginal hostility has several explanations. Fear, racial hatred and the Aboriginal resistance certainly contributed to that over-reaction; but given the 'peaceable' disposition of the Pallittorre and many other Aboriginal bands in Van Diemen's Land, can such factors account for the ferocious nature of British violence? At least two writers have suggested that colonial powers have seen racial others as inherently criminal and necessarily productive of social chaos. Winthrop Jordan suggests that free African Negroes in America were seen to be potentially if not actually in a state of insurrection. Barry Morris recently argued that force was seen by colonists as a necessary part of black-white contact in colonial New South Wales; this perception was prompted and legitimated by constructions of Aborigines, based on real and imagined fears, as treacherous savages always likely to undermine the colonising effort. The perception that force was necessary pointed to an inherent instability of British power in colonial situations, giving rise to a culture of

\footnotetext{
${ }^{42}$ See Ryan 1981, p. 97, for a further example.

${ }^{43}$ See Ryan, 1981 p. 118; Shaw (ed) 1971, pp. 48, 54.

${ }^{44}$ Ryan 1981, p. 119.
} 
terror which governed colonists' relations with Aborigines in colonial New South Wales. ${ }^{45}$

Following Jordan and Morris, free or uncontained Aborigines can be characterised as potential or actual insurrectionists who had to be controlled by force. The record for Van Diemen's Land, including both Aboriginal and British actions, supports such a characterisation. Certainly the record shows that Aborigines in Van Diemen's Land refused to accept the theft of their lands. On the British side, perhaps the most telling evidence is the decision in the early 1830 s by Arthur and Robinson to 'round up' West Coast Aborigines who posed no threat to British occupation. ${ }^{46}$ The record of British violence in Pallittorre country, certainly after William Knight's death, suggests emphatically that most colonists there felt it necessary to use force against the local Aborigines; and there can be little doubt that Aboriginal violence, relatively limited though it was, consolidated such perceptions.

Several prominent colonists who assessed the conflict between black and white argued that force was necessary in dealing with Aborigines. Arguments for force often drew links with perceived Aboriginal savagery and the need for force. In an analysis of the potential value of the black line, the Launceston Advertiser owner and editorialist John Pascoe Fawkner argued that the capture of the blacks 'cannot be achieved without bloodshed'-the ability of the blacks to disappear into the bush and avoid apprehension meant that force was necessary if they were to be contained. The only way to prevent 'their deadly incursions' was 'by shooting a few of them'. ${ }^{47}$ Colonists giving evidence to the Aborigines' Committee believed that force was necessary. Roderick O'Connor, for example, thought it 'impossible to suppress them by open force'; the Aborigines should be fought not openly but in a silent war marked by the genocidal ambush. O'Connor advocated 'some of the worst characters would be the best to send after them', citing a colonist called Douglas Ibbens who had killed half the eastern tribe 'by creeping upon them and firing amongst them with his double-barrelled gun'. ${ }^{48}$ John West also felt that force was necessary to subjugate the Van Diemen's Land 'savages'. In 1852, West wrote that the consequences of the occupation for indigenous people are of little concern because the 'original occupation of this country necessarily involved most of the consequences which followed'. Like the 1830 Aborigines' Committee, West blamed the convicts for inflicting death and destruction on the Aborigines. But in West's view the Aborigines themselves were chiefly to blame, since as savages they were unable to comprehend the laws of civilisation: 'the barbarian that cannot comprehend laws or treaties, must be governed by bribes, or force. ${ }^{49}$

Although historians such as A.G.L. Shaw have argued that Governor Arthur was genuinely concerned to protect the Aborigines in Van Diemen's Land, ${ }^{50}$ the record of events does not lend substance to the proposition. On the contrary, the evidence suggests that both the British government and Arthur, along with most colonists, believed that force was necessary, certainly if the Aborigines refused to accept British

\footnotetext{
${ }^{45}$ Jordan 1974, pp 221-2; Morris 1992, pp 72-87.

${ }^{46}$ Ryan 1981, ch10; Robson 1983, pp 249-50; Pybus 1991, pp 127-29.

${ }^{47}$ Launceston Advertiser, 27 September 1830.

${ }^{48}$ Shaw (ed) 1971, p. 55.

${ }^{49}$ West 1852, p. 96; Shaw (ed) 1971, pp. 35-41.

${ }^{50}$ Shaw 1980, pp. 123-34.
} 
authority. David Neal has recently shown that in New South Wales the rule of law was not applied in order to protect Aborigines; ${ }^{51}$ the same is the case for Van Diemen's Land. Arthur's governorship is marked by a failure to prosecute the many recorded massacres perpetrated against Aborigines by parties of colonists including police and soldiers, the revenge massacre for William Knight's death being but one example. This failure suggests Arthur believed force was necessary. Bronwyn Desailly has convincingly shown that the British government was prepared to condone the use of force to suppress Aborigines who challenged the British occupation, although it sought to conceal such condonement. ${ }^{52}$ It is not surprising then, that from the time Aborigines began to seriously threaten the British invasion of their hunting grounds, Arthur's policy reads as a sequence of measures involving the forceful repression of Aboriginal resistance. ${ }^{53}$ In the late 1820s Arthur actually adopted a formal policy of terrorising the Aborigines out of the 'settled districts', a policy which sought to move between the threat and the use of force. $^{54}$ It makes no difference, as Shaw has argued, that Arthur may have been powerless to stop atrocities against Aborigines-the point is that his policy both facilitated and encouraged atrocities such as those committed against the Pallittorre. Reynold's most recent work suggests that Arthur himself was aware of this. ${ }^{55}$

One outcome of seeking to generalise about the causes of Aboriginal deaths on an Australia-wide basis, or even a colony-by-colony basis, is that experience at the local level can be obscured. What use is a generalised view if it does not accord with the record of evidence in specific places? History is as much, if not more so, about the particular as the general. A generalised view, if it is to aspire to validity, must follow detailed investigation of local places; it must reflect regional variations and similarities, not subvert them to a general view. The dangers for the integrity of historical scholarship inherent in generalised versions of early colonial conflict are exacerbated when high-profile historians seek to popularise comfortable and sanitised general versions. Death by disease is no doubt a less culpable notion than death by violence for a clientele enamoured of a celebratory version of Australia's past.

The discussion above shows that Blainey's assertion that disease was responsible for most Aboriginal deaths simplifies and distorts the wider story of Aboriginal deaths in the wake of colonisation. While agreeing that disease and other factors, all linked to colonisation, were responsible for most Aboriginal deaths, Reynolds asserts ${ }^{56}$ that between 1788 and the 1930s at least 20,000 Aborigines in Australia were killed by whites or their agents, some of whom were native police. Plomley argues that in Van Diemen's Land, starvation caused by the British occupation of hunting grounds was one significant cause of Aboriginal deaths. ${ }^{57}$ The importance of local studies lies in recognising that different factors contributed to most deaths in different places. In many places, certainly in Tasmania, it is not possible to tell how many Aborigines were killed,

\footnotetext{
${ }^{51}$ Neal 1991, pp. 17-8, 58, 78-80.

${ }^{52}$ Desailly 1977 , ch. 3 .

${ }^{53}$ Robson 1983, pp. 210-20.

${ }^{54}$ Desailly 1977 , ch. 3.

${ }^{55}$ Reynolds 1995, p. 108.

56 Reynolds 1982, p. 122.

${ }^{57}$ Plomley 1992, p. 15.
} 
how many died from disease, or how many died from starvation. According to the historical record, the chief cause of Aboriginal deaths in Pallittorre country was the promiscuous massacre. Evidence that disease had lesser impact than killing in Pallittorre country was the ability of those not killed to remain healthy. As late as 1834 Robinson was told by an unnamed Aboriginal woman who only very recently had been living with the Pallittorre that there were 'plenty' of blackfellas still in the district. Reports of raids for food on colonists' properties at Chudleigh, in the west of Pallittorre country, corroborate the woman's evidence. ${ }^{58}$ In any case, as Reynolds has pointed out, the important point from the perspective of national debate about white Australia's obligations to Aborigines in the wake of native title is not how many died from what cause, but asserting that disease accounted for most and neglecting to emphsise the extent of killing - the course Blainey chose during the native title debate-distorts the reality of contact violence. ${ }^{58}$ As I am arguing, this distortion is further exaggerated by national versions of the past which do not allow for local variations.

\section{Irresistible inevitability and human agency}

In his The Invasion of America, Francis Jennings ${ }^{60}$ used the term 'the conquest myth' to characterise colonial justifications of indigenous dispossession which emphasise the inevitability of the process. According to this myth, savagery and civilisation were opposites, the natives incapable of civilisation and hence full humanity, the colonists 'ennobled in their contest with the dark powers of the wilderness'. Savages were creatures of the wilderness and would always remain so, whereas the civilised were 'required by divine sanction or the imperative of progress to conquer the wilderness and make it a garden'. Fundamentally, all prescriptions contained within the myth were in some way fated - as Jennings puts it, 'it was all inevitable'. As a means of rationalising the gruesome reality of Aboriginal dispossession, various elements of the conquest myth were re-inforced during the early decades of the British occupation of Tasmania. Aborigines were routinely perceived as objects of savagery, if not the most uncivilised savages on earth. In the early 1850s, the conquest myth was popularly articulated in Tasmania by the Launceston-based preacher, editor and historian John West. ${ }^{61}$

West's views on the inevitability of conquest are important in this story. West was an immensely influential journalist and preacher in northern Tasmania during the 1840s and $1850 \mathrm{~s}^{62}$ His views provide verification that the conquest myth was afoot in Van Diemen's Land, and his contribution to racist ideology, at least in Tasmania, has been considerable. West found that the occupation of Aboriginal land in Van Diemen's Land was just in the following terms:

The right of wandering hordes to engross vast regions forever to retain exclusive property in the soil, and which would feed millions where hundreds are scattered-can never be maintained. The laws of increase seem to suggest the right of migration: neither nations nor individuals are bound to tarry on one spot, and die. The assumption of sovereignty over a savage people is justified by necessity-

\footnotetext{
${ }^{58}$ Plomley 1966, p. 903.

${ }^{54}$ Jennings 1975, pp. 29-31

${ }^{61}$ Morgan 1992, pp. 143-50; West 1852, pp. 92-96.

${ }^{62}$ Australian Dictionary of Biography 1966, pp 590-92.
} 
that law, which gives to strength the control of weakness. It prevails everywhere: it may be either malignant or benevolent, but it is irresistible. ${ }^{63}$

Three closely related ideological positions inform West's justification of occupation. West argues firstly in Lockean terms ${ }^{64}$ that the 'laws of increase seem to suggest the right of migration'. Migration for West is in fact necessary, for without it both individuals and nations will perish. Secondy, the occupation is justified by the social-Darwinist law which 'gives to strength the control of weakness'. This law prevails everywhere, its moral implications being coincidental to its ubiquity. Thirdly, West wrote that it is not in the nature of civilisation to exalt the savage'; the relation of the savage to the white (West's word) 'can only be that of an alien, a slave'. ${ }^{65}$ Three natural laws then, those of increase, the dominance of the strong over the weak, and the incorrigibility of the racial savage, render inevitable a just and necessary occupation of Aboriginal land. These are laws which impel and dictate broad historical forces which human society is obliged to accept, indeed must accept because they are irresistible. In part, West was responding to a widely felt ambivalence in the 1830 s and 1840 s about British presence in the colony and the implications of that presence for the island's Aboriginal population. W.P. Weston, for example, spoke for many colonists when he wrote

Whatever may be the evils of society in a state of civilization they are assuredly less in character and degree than those of savage life; and I can never regret that the fair and beautiful country of Tasmania has been entirely reclaimed from the dominion of the debased and treacherous Aborigines; though I cannot but comment that it has been done in part in sad violation of those laws established by Him who hath made of one blood all men to dwell upon the face of the earth ${ }^{66}$

West's justification for England's 'assumption of sovereignty' was thus one early expression of a process of denial of responsibility which is still evident at the present time.

Geoffrey Blainey informed his analysis of the implications of the Native Title Act with an ideological positioning similar to that advanced by West. Attributing a major population increase to the pre-Christian invention of agriculture, Blainey argues that for 5,000 years the strong have invaded the weak; and that the Aboriginal 'way of life was bound to be overthrown eventually because it supported so few people on so much land'. Blainey also offers a modern version of West's law concerning the incorrigibility of the savage. The Native Title bill 'is introducing a form of ownership and an attitude to the land that served the world well in the Stone Age but will be self-defeating in the 21st century'. And despite an historiography that compellingly documents the deliberate process of marginalisation, Blainey argues that the 'main reason' why Aborigines are 'less fortunate' in the fields of

health, education and work opportunities... is because their traditional culture, for all its merits, does not fully equip them for the modern world. The new emphasis

\footnotetext{
${ }^{63}$ West 1852, pp. 92-96.

64 Yarwood and Knowling 1982, p. 95.

${ }^{65}$ West 1852, pp. 92-96.

ch Weston Reminiscences, pp 93-4; see also Dove 1842, pp 247-8; Plómley 1966, pp 202-3:

Reynolds 1995, pp. 83-85.
} 
on Aboriginal ownership of land is reinforcing culture. In that sense, it is a backward step. ${ }^{67}$

The inevitability argument operates on two levels, the inevitability of the occupation itself, and the inevitability of Aboriginal deaths once the occupation had occurred. The argument that historical processes inducing the inevitability of invasion might be at work is supported by some superficial evidence. Five thousand years of invasions and almost continuous war suggest an entrenched desire to dominate others. But the issue is more complex and problematic than either West or Blainey allow. Robert King has argued, for example that important strategic, trade and social factors figured prominently in a long-running debate which culminated in the occupation of Aboriginal Australia. And recently Allan Frost has argued that the British occupation of Australia was part of a British Board of Trade plan to establish a global free trade network. ${ }^{68}$ Such choices challenge the notion of human society impelled to act by instincts beyond its control. Once again Blainey's historical method reduces a set of complex processes to simplified generalisation.

West asserts that occupation 'necessarily involved most of the consequences which follow'; ${ }^{69}$ not only was the invasion necessary and just, so too were the consequences which followed! Is such a view beyond dispute? If we accept the view that the bulk of colonists thought force was a necessary, it was more or less inevitable that many Aborigines would die violent deaths, although there are many examples of colonists who were able to enjoy relatively harmonious relations with Aborigines, primarily when control of land was not an issue. Ryan shows, for example, that relations between Aborigines and sealers along the north coast of Van Diemen's Land in the early years of the nineteenth century were in some respects mutually beneficial and certainly more harmonious than those with agriculturalists and graziers from about 1810 onwards. ${ }^{70}$ The apparent ability of individuals such as Punch to co-exist with the Pallittorre also shows that conflict and death were not inevitable. ${ }^{71}$ In any case, neither the argument for the inevitability of invasion, nor the belief that force was a necessity, should obscure the fact that in many cases of massacre, actions followed premeditated decisions. If we held that the belief that force was a necessity meant that mass killings of Aborigines was inevitable and hence somehow an inevitable fate, we dispense with the notion that individuals and states ought to be held accountable for their actions, irrespective of when those actions were committed. In Van Diemen's Land prevailing ideas and circumstances helped shape decisions, but individuals made decisions and committed actions. Beliefs, ideas and circumstances may prompt decisions and help explain subsequent actions, but they cannot exonerate individuals from responsibility for those actions, especially in the absence of substantive evidence of self-defence. Just as the Pallittorre were not the passive victims of their invaders, nor were the invaders the passive victims of their own beliefs, prejudices and prevailing circumstances. That the Van Diemen's Land Aborigines were systematically massacred was never inevitable; mass killing by massacre was the outcome of consciously taken decisions.

\footnotetext{
${ }^{67}$ Blainey, 24 July 1993.

${ }^{68}$ King 1990, pp. 13-20; Frost 1992, pp. 4-11.

${ }^{69}$ West 1852, p. 92.

${ }^{70}$ Ryan 1981, chs. 3 \& 4.

${ }^{71}$ Plomley 1966, pp. 218.
} 
When combined with representations of Aborigines as anachronistic cultural objects, the inevitability argument on both levels-invasion and deaths-is calculated to exonerate past historical actors for responsibility for the mass murder of Aborigines; it serves also to excuse contemporary Australians from the responsibility to provide Aborigines with necessary and just human rights, ${ }^{72}$ usually conceived as some form of land rights, and the provision of basic services such as health care and educational opportunity. The effect of the inevitability argument is to render the decision to invade and the deaths which followed of lesser significance in the destruction of Aboriginal society than the broad historical forces which impelled those lesser, contingent decisions. As did West, Blainey is seeking to swing the pendulum of public opinion away from an acceptance of pre-meditated killing as a major cause of Aboriginal deaths and towards a more comfortable view of the past-that Aborigines lacked both the biological capacity and the cultural sophistication to adapt to the inevitable arrival of a superior western civilisation. Blainey and his predecessor West give us essentially colonial versions of the past; their histories document Australian history as the story of western progress, as the story of broad historical forces to which individual agency is always susceptible; they present historical pasts in which the indigenes are required to assimilate into western culture and society, or perish. Both use their versions of the past to argue, each for his own generation, that neither compensation nor reparation to Aborigines is necessary.

\section{Conclusion}

The historical debate which accompanied the High Court's Mabo decision and the subsequent Native Title Act 1993 is one expression of a 'contest to control the memories that nourish national consciousness and so shape our future: ${ }^{73}$ Given such lofty stakes, it is crucial that positions put by protagonists such as Blainey be challenged, certainly on historical grounds, and on moral grounds too. Both grounds involve questions pertaining to the relevance and methodology of historical scholarship in the field of race relations. In 1990 Peter Read wrote that historians have seldom addressed 'the question of whether we, the present, have any responsibility towards rectifying the deeds of earlier generations'. ${ }^{74}$ The High Court ruling that "'Australia" is morally illegitimate to the extent that it is founded on European denial of the continent's prior ownership by indigenous people, ${ }^{75}$ however, has prompted debate on the issue. While Tim Rowse has expressed the view that such matters are 'endlessly ponderable ${ }^{76}$ positions put by Blainey and the moral philosopher Raimond Gaita suggest a polarisation exists. In many ways this debate and the 1996-97 Wik debate, in which the High Court ruled that Native Title and pastoral leases could co-exist ${ }^{77}$ suggest the ambivalence which characterised the views of men such as Weston is still evident in Australian society. As might be expected, the focus of these debates is whether or not land should be returned to

\footnotetext{
${ }^{72}$ Rowse 1993 , p. 229.

${ }_{73}$ McQueen 1994, p. 54.

${ }^{74}$ Read 1990, p. 298.

${ }^{75}$ Rowse 1993, p. 229.

${ }^{76}$ Rowse, 1993, p. 229.

${ }^{77}$ For comment on the High Court's Wik decision, see, for example, The Australian, 21 March and 15 April 1997
} 
Aborigines. Blainey does not address the issue of an inherited responsibility, but rather points out perceived negative outcomes (in his view) if the responsibility is accepted. Blainey argues that no further land should be given to Aborigines for a number of reasons: the average Aborigine has 12 times more land than the average nonAborigine-an over-simplification, in my view, which distorts the reality of Aboriginal dispossession; a potential weakening of the 'sovereignty and unity of the Australian people', a claim which assumes that such sovereignty and unity actually exists; the threat to economic prosperity derived from mining, a claim for which the evidence is contradictory; that ownership of land is not vital for the survival of any Australian family, an argument which ignores the importance of land in formulations of Aboriginal identity; and the High Court's appropriation of the Parliament's right to embody contemporary moral values in law, a claim which forgets that the parliament drafted and passed the Native Title Act. ${ }^{78}$

Gaita, on the other hand, argues that reparation in the form of Native Title is necessary because nothing less than reparation will redress 'the crimes of our political ancestors' and restore to Aborigines their 'full human status', the depth of their 'moral and spiritual being', which was denied by the application of terra nullius ${ }^{79}$ and by the ubiquity of the conquest myth. If the obligation to restore full human status to Aborigines provides one basis for an argument for present responsibilty, this paper suggests at least one other. Its illegality aside, one of the most morally culpable aspects of the occupation in Van Diemen's Land, and in fact all of Aboriginal Australia, was the persistent choice, when taking the land, to employ the promiscuous massacre. Many Aborigines with whom I have worked speak of the enduring cultural and personal trauma bequeathed by knowledge of those massacres. ${ }^{80}$ This trauma and the attendant moral culpability is intensified by the fact that in almost every other aspect of social life the British invaders rigorously applied the rule of law. As most historians would know, reparation for war crimes is not a novel notion. When taken together, the illegal claim to the country, the morally culpable means used to acquire and retain it, and the disastrous consequences for Aborigines, which persist to this day, provide a very solid basis for the argument that we do have an obligation to rectify past wrongs. In the long run, no amount of over-simplified and politically motivated 'history' will deny that obligation. And herein lies the importance of local studies.

Local studies enable us to engage with the particular, the actual, and the complex, to explore wider issues at close range, and perhaps understand more intimately the living actuality of the time. The argument that colonisation in Australia was an abstract force to which humans were bound to defer, or 'a structure imposed on local practice ${ }^{81}$ tends to deny the diversity and complexity of relations between indigenes and colonisers in local places at different 'historical moments'. ${ }^{82}$ This argument tends also to deny the level of agency open to the participants in those relations. Similarly, explaining Aboriginal deaths in terms of the abstraction 'disease' obscures the complex of ways and circumstances in which indigenous people died. To claim validity, a generalised view

\footnotetext{
${ }^{77}$ Blainey, 10 November 1993.

${ }^{7 y}$ Gaita, 19 November 1993.

${ }^{80}$ See Cameron and Matson-Green 1994, p65.

${ }^{81}$ Stoler 1989, p135-6., in Thomas 1994, p13.

${ }^{82}$ Thomas 1994, p14.
} 
must reflect detailed investigation of local places; it must reflect regional variations and similarities, not subvert them to convenient generalisation. Historical opinion, especially on an issue which many observers believe has deep implications for the moral character of contemporary Australian society ${ }^{83}$ should always proceed from a rigorous historical analysis of available evidence and from generalisations which take account of the diversity and complexity of local experience.

\section{Acknowledgments}

Thanks to Richard Barwick for his help with preparing the maps for publication.

Shayne Breen lectures in Aboriginal Studies in Riawunna, Centre for Aboriginal Education, at the University of Tasmania. Dr Breen holds a PhD in history from the University of Tasmania, and he is descended from the Aboriginal peoples of Central Victoria.

\section{References}

Australian Dictionary of Biography, vol 2, 1788-1850, 1966, Melbourne: Melbourne University Press, pp 590-92.

The Australian, 21 March and 15 April, 1997.

Blainey, Geoffrey 1993, 'Mabo assails equality', The Age, 24 July.

Blainey, Geoffrey 1993, 'Mabo decision looked back through modern blinkers', The Age, 31 July.

Blainey, Geoffrey 1993, 'Mabo: what Aboriginals lost', The Age, 10 November.

Blainey, Geoffrey 1993, 'Land rights for all', The Australian, 10 November.

Cameron, Patsy and Matson-Green, Vicki 1994, 'Pallawah women: their contribution our survival', in Tasmanian Historical Research Association, Papers $E$ Proceedings, Hobart, vol. 41, no. 2, pp. 65-70.

Clark, Julia 1987, 'Devils and horses: religious and creative life in Tasmanian Aboriginal society', in Michael Roe (ed.), The Flow of Culture: Tasmanian Studies, Canberra:

Australian Academy of the Humanities, pp. 50-72.

Cowlishaw, Gillian 1993, 'Mabo breeds a sinister new form of racism, The Age, 31 July.

Cubit, Simon 1987, 'Squatters and opportunists; occupation of lands to the westward to $1830^{\prime}$, in Tasmanian Historical Research Association, Papers $\mathcal{E}$ Proceedings, Hobart, vol. 34 no. 1, pp. 7-13

Depositions concerning the death of William Knight 1827, Chief Secretary's Office, 1/316, Archives Office of Tasmania, Hobart.

Desailly, Bronwyn 1977, The Mechanics of Genocide, MA thesis, University of Tasmania, Hobart.

Dove, Thomas 1842, 'Moral and social characteristics of the Aborigines of Tasmania, as gathered with intercourse with the surviving remnant of them now located on Flinder's Island', Tasmanian Journal of Natural Science, vol. 1, pp 247-8.

Field correspondence 71/227, Archives Office of Tasmania, Hobart.

\footnotetext{
${ }^{83}$ Gaita, 19 November 1993; Read 1990, pp. 291-98; Rowse 1993, pp. 229-252.
} 
Frost, Alan 1992, 'Botany Bay, Nootka Sound and the beginnings of Britain's imperialism of free trade', Bulletin of the Centre for Tasmanian Historical Studies, Hobart, vol. 3 no. 2, pp. 4-11

Gaita, Raimond 1993, 'Mabo is simple humanity', The Age, 19 November.

Griffen, Daniel 1893-4, 'Deloraine past and present', in K. Bonney (ed.) Early Deloraine: the writings of Louisa Meredith and Daniel Griffen, Launceston: n.d., no publisher, pp. 12-86.

Griffiths, Tom 1987, 'Past silences: Aborigines and convicts in our history-making', Australian Cultural History, no. 6, pp. 18-31.

Hartwig, M.C. 1971, 'Aborigines and racism: an historical perspective', in F.S. Stevens (ed.), Racism the Australian Experience, ed, Sydney: Australia and New Zealand Book Co, pp. 9-24.

Hobart Colonial Times, 6 July 1827

Isaac, Rhys 1982, The Transformation of Virginia: 1740-90, Chapel Hill: University of North Carolina Press.

Jennings, Francis 1975, The Invasion of America, Chapel Hill: University of North Carolina Press.

Jordan, Winthrop D. 1974, The White Man's Burden, London: Oxford University Press.

King, Robert 1990, The Secret History of the Convict Colony, Sydney: Allen \& Unwin.

The Last Tasmanian: a story of genocide, 1976, (feature documentary), Sydney: Artis Film Productions Pty Ltd, producer Tom Haydon

Launceston Advertiser, 27 September and 4 October 1830.

McQueen, Humphrey March 1994, 'Manning Clark revisited', in 24 Hours, Sydney, pp 54-56.

Morgan, Sharon 1992, Land Settlement in Early Tasmania: Creating an antipodean England, Melbourne: Cambridge University Press.

Morris, Barry 1992, 'Frontier colonialism as a culture of terror', in Bain Attwood and John Arnold (eds), Power, Knowledge and Aborigines, Melbourne: La Trobe University Press \& National Centre for Australian Studies, Monash University, (a special edition of Journal of Australian Studies), pp. 72-87.

Neal, Robert 1991, The Rule of Law in a Penal Colony: Law and Power in Early New South Wales, New York: Cambridge University Press.

Plomley, N.J.B. 1966, Friendly Mission, Hobart: Tasmanian Historical Research Association.

Plomley, N.J.B. 1992, The Aboriginal/Settler Clash in Van Diemen's Land 1803-31, Launceston: Queen Victoria Museum \& Art Gallery.

Pybus, Cassandra 1991, Community of Thieves, Melbourne: Heinemann.

Read, Peter 1990, 'Good historians and true-revising Aboriginal history', Victorian Historical Journal, Melbourne vol. 61, no. 4, pp. 291-98.

Reynolds, Henry 1982, The Other Side of the Frontier, Melbourne: Penguin.

Reynolds, Henry 1993, 'Laws of the British empire recognised native title', The Age, 11 November

Reynolds, Henry 1995, Fate of a Free People, Melbourne: Penguin. 
Robson, Lloyd 1983, A History of Tasmania from the earliest times until 1853, Vol 1, Melbourne: Oxford University Press.

Rowse, Tim 1993, 'Mabo and moral anxiety', in Meanjin, Melbourne, vol. 52, no. 2, pp. 229-252.

Ryan, Lyndall 1981, The Aboriginal Tasmanians, St. Lucia: University of Queensland Press.

Shaw, A.G.L. 1980, Sir George Arthur, bart, Melbourne: Melbourne University Press.

Shaw, A.G.L. (ed), 1971, Van Diemen's Land: Copies of all correspondence... on the subject of the military operations...against the Aboriginal inhabitants..., Hobart: Tasmanian Historical Research Association.

Skemp, J.R. 1964, A History of the municipality of Deloraine, n.p.

Thomas, Nicholas 1994, Colonialism's Culture, Cambridge: Polity Press.

Veale, Veda n.d., Women to Remember, St Helens: self published.

West, John 1852, A History of Tasmania, vol. 2., Launceston: Henry Dowling.

Weston, W.P. 1843, Reminiscences of Colonial Life in Tasmania by an OldConvict, unpublished MS, Box 5, ENVC, Weston papers, Queen Victoria Museum \& Art Gallery, Launceston.

Yarwood, A.T. and Knowling, M.J. 1982, Race Relations in Australia, Sydney: Methuen. 